\title{
EFFECT OF "WINDOWS" MAPPED BY GEOPHYSICAL METHODS ON GROUNDWATER QUALITY
}

\author{
Lærke Thorling ${ }^{1}$, Kurt I. Sørensen ${ }^{2}$ and Vibeke Ernstsen ${ }^{3}$. \\ 1. Árhus County, dept. natural resources, Lyseng Allé 1, DK-8270 Højbjerg, Denmark. \\ 2. University of Arhus, dept of Earth Sciences, Finlandsgade 8, DK-8200 Århus N, Denmark \\ 3. Geological Survey of Denmark, Thoravej 8, DK-2400 København NV, Denmark.
}

\section{INTRODUCTION}

Geophysical methods turns up to be very useful, when vulnerability of ground waters is mapped in areas with a heterogeneous geological setting. In Denmark groundwater accounts for almost $100 \%$ of the drinking water resource. Only groundwater that satisfy the quality standards of drinking water is used. Thus nitrate becomes a mayor threat in rural areas where nitrate loads generally exceed the quality limit of $50 \mathrm{mg} / \mathrm{l}$. Previous work in Denmark concentrated on nitrate reduction under homogeneous geological condition $/ 1 /$ In areas with thick clay layers above the aquifer nitrate was found to penetrate about $3.8 \mathrm{~m}$ into the till and never reached the groundwater $/ 2 /$. In sandy areas nitrate was reduced in the aquifer by pyrite at the redox boarder where oxygen and nitrate were depleted at the same depth and below reduced conditions with iron and mangese was found. $/ 3 /$ These homogeneous conditions accounts for about $50 \%$ of the Danish ground waters, but in the rest of the country the geological settings are often very heterogeneous due to disturbance form ice movements during the last glaciation. Therefore both the top layers above the aquifer and the aquifer are very irregular with layers of alternating grain size from impermeable sediments with up to $15 \%$ clay minerals to coarse gravel deposits. The aim of this work is to study the effect of geological heterogeneity on groundwater quality and redox conditions in the aquifer. This work is part of the Danish Environmental Research programme (1992-1996).

\section{METHODS}

The study area was chosen at Grundfør, north of Århus, Denmark, with intensive agriculture and many greenhouses. The Pulled Array Continuous Electrical Profiling technique was used to map the geological variation of the near surface geology. The Ellog Auger Drilling method was used to map the groundwater quality and hydrological conditions in the aquifer. Groundwater samples were analyzed for all major constituents according to standard methods. Oxygen, $\mathrm{pH}$, were measured in the field in a flow cell connected to the Ellog Auger. Measurements could be made on groundwater without atmospheric contact. Nitrite, iron and other unstable compounds were measured in a field laboratory. Measurements on Freon were made at USGS, to date the groundwater. All groundwater samples were assign a redox index (see table 1). Sediment cores were collected at two locations and analyzed for organic matter, calcite, pyrite and clayminerals.

\section{RESULTS AND DISCUSSION}

Figure 1 shows an Iso-ohmmeter map for the Continuos Electrical Profiling $30 \mathrm{~m}$ Wenner array at Grundfør. White colours can be interpretated as tertiary fat clay, gray colours as more coarse clayey till and dark colours indicate sand, with no protective clay layers. The investigations were concentrated in the transect south of Well no 79.920, but similar conditions were also found in the northern transect. The heterogeneity of the sediments at the edge of the window is shown on figure 2. A larger aquifer is found in the southern part of the trace. The edge of the window is rough with repeated layers of clay and sand. In this environment a great variety of redox conditions were found, due to slow reduction reactions compared to the velocity of the groundwater. Table 1 shows the chosen definitions for redox zones. Note especially the existence of a zero zone where neither oxygen, nitrate nor iron is present. In several wells all these redox zones were found in the 
groundwater. The presence of anoxic redox zones without iron in these sediments shows that nitrate is able to penetrate below the redox boarder which is established by dissolved oxygen since the last glaciation form infiltrating oxic water. Redox zone 3 and 4 have a chemical disequilibrium between sediments and groundwater and can only be found below areas of heavy nitrate loads $/ 5 /$. In Grundfør nitrate was found to penetrate more than $20 \mathrm{~m}$ below the old redox boarder, indicating unstable redox conditions.

\begin{tabular}{||c|c|c|c|c|c|c||}
\hline \hline Redox index & Redox zone & $\mathrm{O}_{2}$ & $\mathrm{NO}_{3}{ }^{-}$ & $\mathrm{NO}_{2}^{-}$ & $\mathrm{Mn}$ & $\mathrm{Fe}$ \\
\hline \hline RZ-1 & Oxic, high $\mathrm{O}_{2}$ & $>2$ & $>1$ & $<0,01$ & $<0,1$ & $<0,1$ \\
\hline RZ-2 & Oxic, low $\mathbf{O}_{2}$ & $\mathbf{0 , 5}-2$ & $>1$ & $?$ & $<0,1$ & $<0,1$ \\
\hline RZ-3 & Anoxic, $\mathrm{NO}_{3}^{-}$ & $<0,5$ & $>1$ & $?$ & $?$ & $<0,1$ \\
\hline RZ-4 & Zero zone & $<0,5$ & $<1$ & $<0,01$ & $?$ & $<0,1$ \\
\hline RZ-5 & Anoxic Ferrous zone & $<0,5$ & $<1$ & $<0,01$ & $>0,01$ & $>0,1$ \\
\hline
\end{tabular}

Table 1. Redox zones found in the Grundfør aquifer, concentrations in $\mathrm{mg} / \mathrm{l}$.

Figure 3 show the chemical variation of the redox sensitive species in well no 22 placed at the edge of the window, where several layers of groundwater is found. In the upper groundwater conditions become gradually more reduced with depth. Nitrate reduction is found few meters below the groundwater table, and a peak of nitrite indicates appears below the penetration depth for oxygen. Only small concentrations of oxygen is found in the upper layer, due to reduction processes in the clayey till during infiltration.

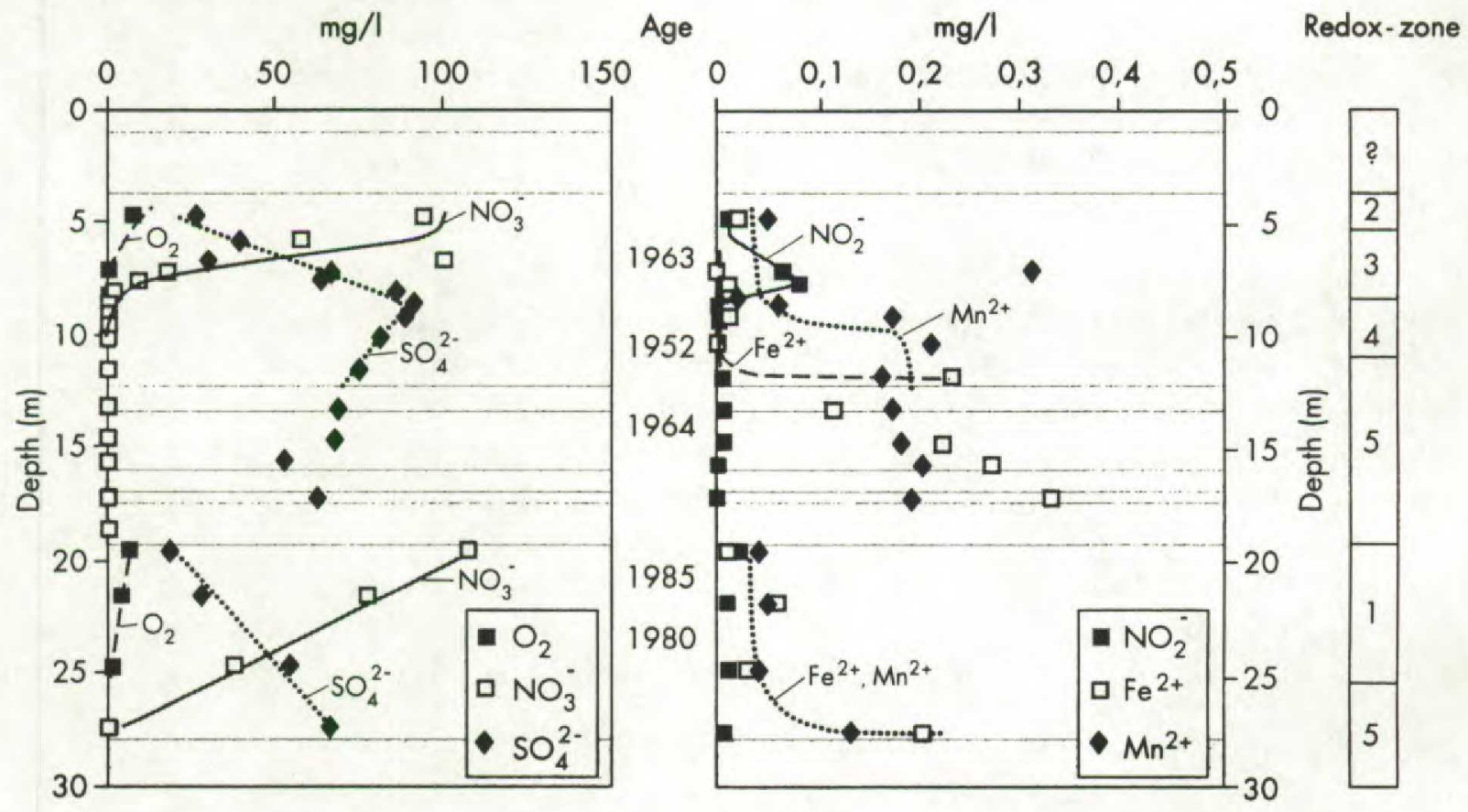

Figure 3. Ground water Chemistry of redox sensitive species and redox index in well no 22 located at the edge of the geological window. Ground water age is determinated by CFC.

Nitrate is infiltrated without any significant reduction. In the bottom of this well a layer with $10 \mathrm{mg} / \mathrm{l}$ of oxygen is found. CFC measurements showed that this groundwater is only about 15 years old, where as the groundwater in the upper part is found to be more than twenty five yeas old. This younger water is expected to infiltrate through the sandy parts of the top soils. The larger permeability gives rise to a larger infiltration than that of the more clayey top layers in the top of the 


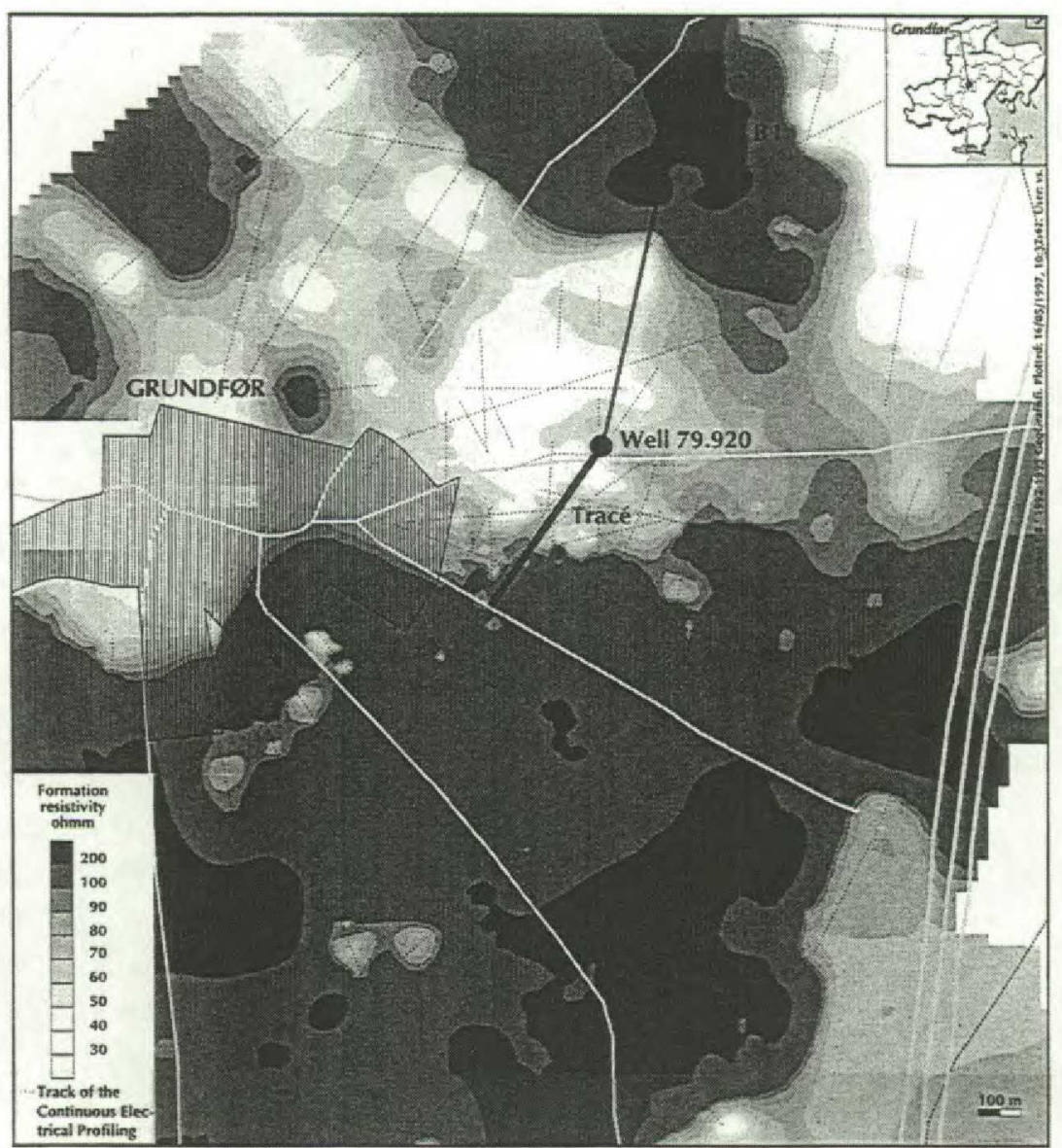

Figure 1. Iso-ohmmeter mapfor the Continouos Electrical Profiling $30 \mathrm{~m}$ Wenner array at Grundfør. White colours can be tertery fat clay gray colours as more coarce clayey till and dark colors indicate sand, with no protective clay layers.

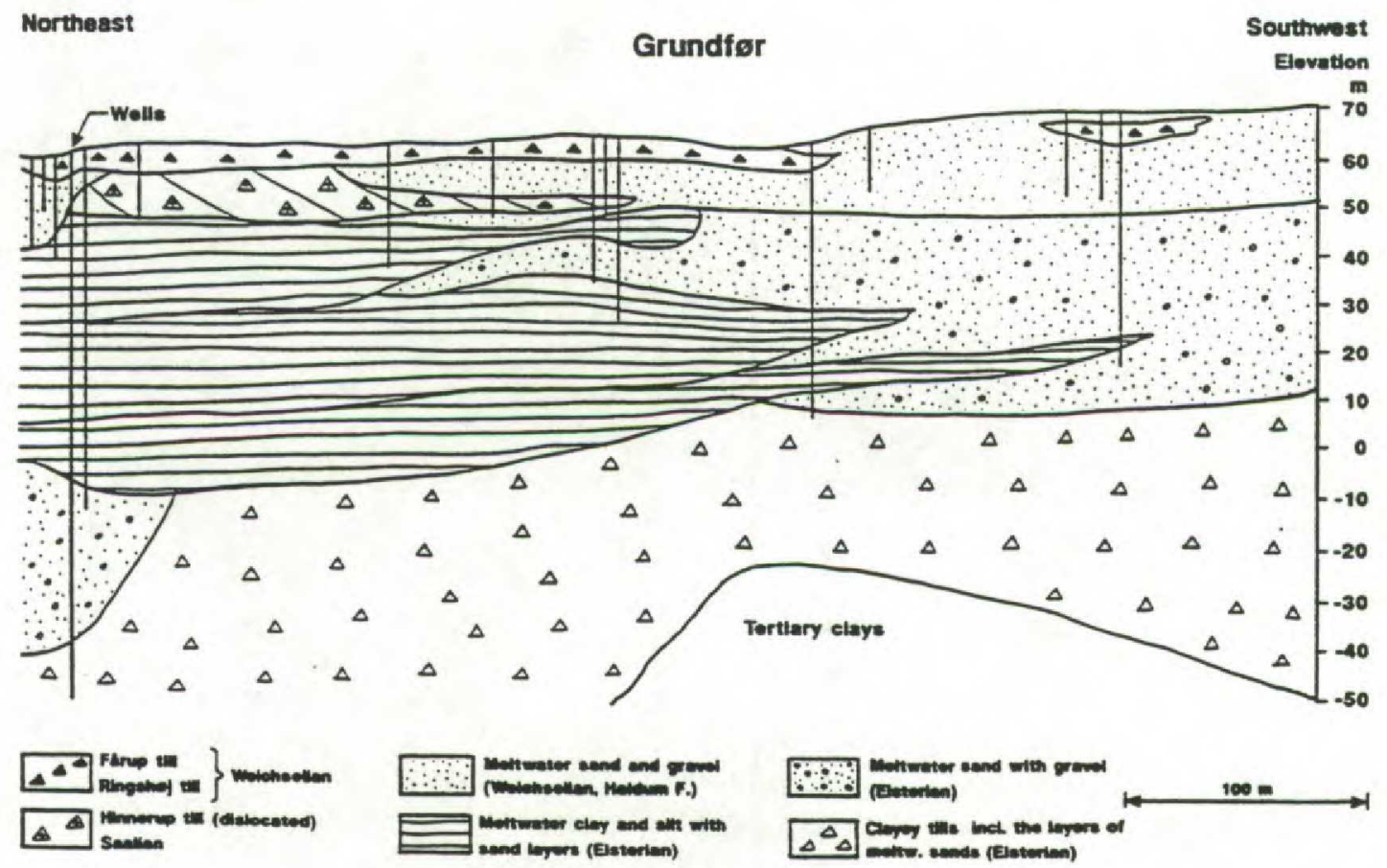

Figure 2. Geological cross section at the trace form Well 79.920 (A) and south. Vertical lines indicate wells. The model integrates data from wells and geophysical measurements./4/ 
well. The heterogeneous geological setting thus gives rise to a very complex flow pattern. Mapping of the surface layer geology is thus very important to identify the areas whit sandy deposits and hence the largest infiltration.

Figure 4 shows an iso-nitrate cross section at the trace. The oxidized water in the bottom of well 22 was found in other wells across the trace, showing a "stream" of young water about $15 \mathrm{~m}$. below the groundwater table. The penetration depth of nitrate varies dramatically across the section form a few meters to more than 40 meters.

\section{CONCLUSION}

Quick and detail mapping is possible with the geophysical methods developed at Århus University, and was a precondition for this work. The Pulled Array Continuous Electrical Profiling technique was used to map the geological variation of the near surface geology. The Ellog Auger Drilling method was used to map the groundwater quality and hydrological conditions in the aquifer. Localization of the sandy parts, "windows" of inhomogeneous top layers were found to be crucial in groundwater protection planning. The varying conditions for recharge due to the distribution of sand and clay in quaternary sediments of an aquifer below arable land gave rise to a pronounced response in the groundwater chemistry. The overall picture showed that water

recharged through the till coverage was partly reduced in the till, while water recharged through the sandy parts had high concentrations of oxygen and nitrate. It was observed that the nitrate polluted groundwater was spread through the aquifer below the reduced waters recharged through the till, indicating very complex flowpatterns. Groundwater was dated by CFC's showing younger water below older water. This flow pattern could only be identified by integration of detailed geological and chemical parameters.

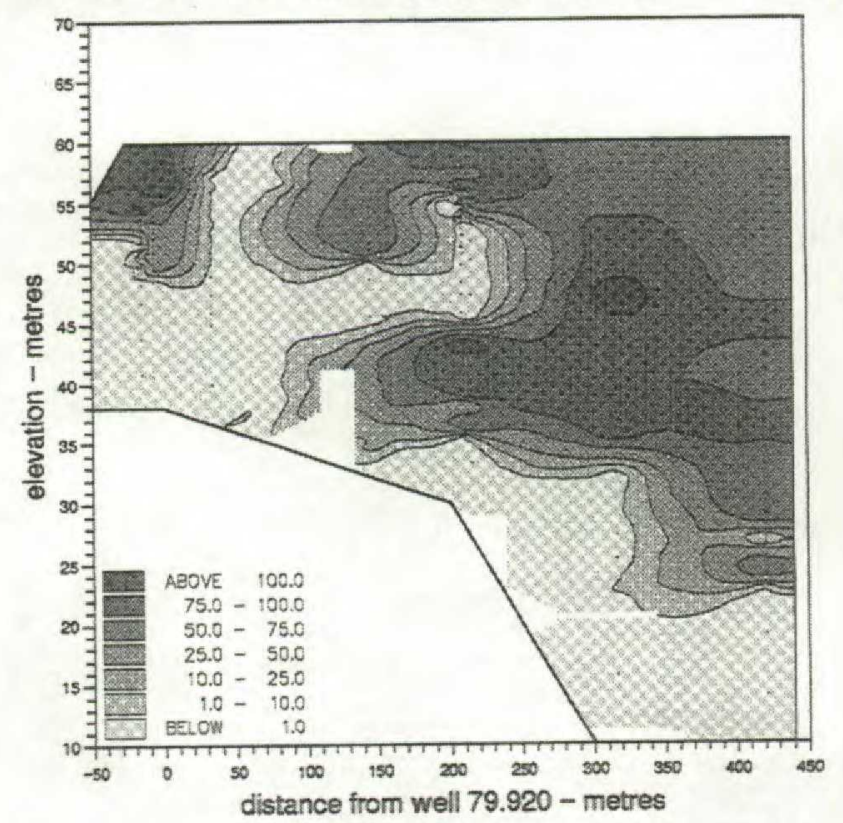

Figure 4. Nitrate at the Grundfør trace'. Iso- nitrate cross section from well no 79.920 (A1) and south.

\section{REFERENCES}

/1/ Nitrogen and Phosphorus in Ground water. Ministry of Environment, National Agency of Environmental Protection, Denmark, 1991. B- abstracts.

/2/ Ernstsen, E., 1996: Nitrate reduction in clayey subsoil. Ph.D. Thesis KVL-Denmark.

13/ Postma, D. et al, 1991: Nitrate reduction in an unconfined sandy aquifer: Water chemistry, reduction processes, and geochemical modeling. Water Resources Res. vol 27 pp 2027-45.

14/ Hansen, M. \& Gravesen, P.,1996 Chapter 10.Geological modelling. In Abbott, M.B. \& Refsgaard, J.C.(red) Distributed Hydrological Models. Kluwer Academic Publishers.

15 / Ernstsen, V. and Thorling, L. (1997) Nitrate and redox zones in a shallow aquifer below arable land (submitted to Ground Water). 